\title{
Development of cannabinoid receptor (CB 2 R) ligands for application in PET studies - where to attach the radiolabel?
}

\author{
Robert Günther ${ }^{1 *}$, Rareş Moldovan', Corinna Lueg$^{2}$, Winnie Deuther-Conrad ${ }^{1}$, Bernhard Wünsch², Peter Brust $^{1}$ \\ From 9th German Conference on Chemoinformatics \\ Fulda, Germany. 10-12 November 2013
}

The cannabinoid receptors type $2\left(\mathrm{CB}_{2} \mathrm{R}\right)$ are involved in many physiological processes but their expression level in healthy and diseased brain has not been unravelled. With positron emission tomography (PET) it is possible to monitor quantitatively very low amounts of compounds labelled with positron emitting isotopes like ${ }^{18} \mathrm{~F}$ in living organisms at high spatial resolution. For application in clinical research, such radiotracers have to show high selectivity and affinity to the target protein.

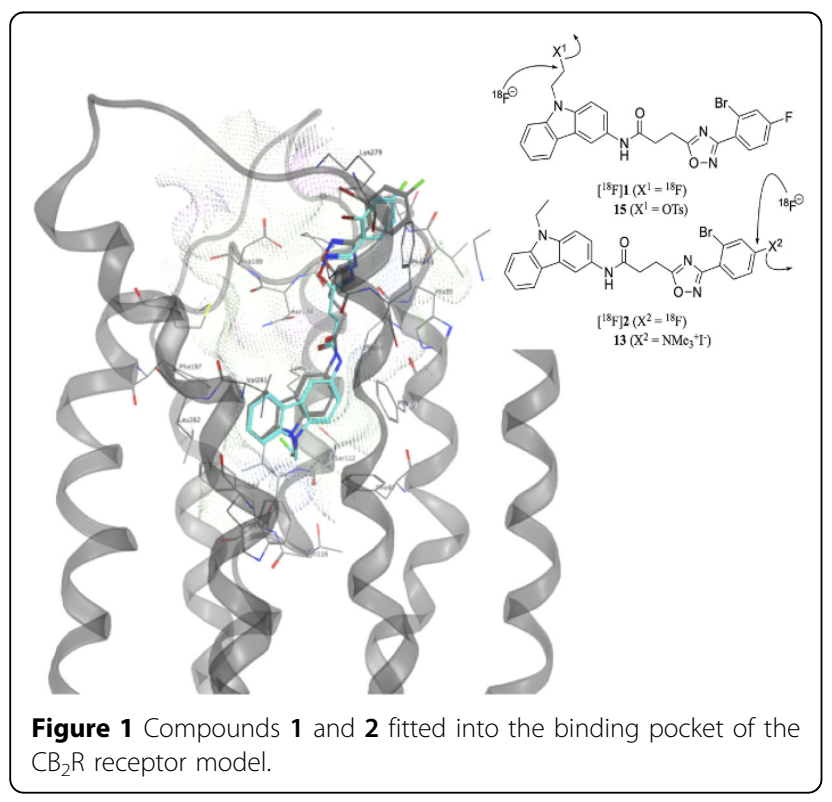

* Correspondence: r.guenther@hzdr.de

'Department of Neuroradiopharmaceuticals, Institute of Radiopharmaceutical Cancer Research, Helmholtz-Zentrum Dresden-Rossendorf, Research Site Leipzig, Leipzig, 04368, Germany

Full list of author information is available at the end of the article
A series of fluorinated $\mathrm{N}$-carbazolyl-oxadiazolyl-propionamides [1] was synthesised and the affinity towards the human $\mathrm{CB}_{2} \mathrm{R}$ was measured in receptor binding studies. Here, we combine our $\mathrm{CB}_{2} \mathrm{R}$ receptor model with 3D-QSAR data [2] to support molecular docking studies employing the MOE software (Version 2012.12 Chemical Computing Group Inc. Montreal. http://www.chemcomp. com). The studies revealed that both the primarily investigated compound $\mathbf{2}$ and the 2-fluoroethyl substituted carbazole derivative $\mathbf{1}\left(\mathrm{K}_{i}=3.6 \mathrm{nM}\right)$ fits well into the binding pocket. Attachment of the fluorine at different positions of the structure does not lead to significantly different poses in accordance with the experimental data. Organ distribution studies on CD1-mice verified our prediction, [3] that $\left[{ }^{18} \mathrm{~F}\right] 1$ and $\left[{ }^{18} \mathrm{~F}\right] 2$ can cross the blood-brain barrier.

\section{Authors' details}

'Department of Neuroradiopharmaceuticals, Institute of Radiopharmaceutical Cancer Research, Helmholtz-Zentrum Dresden-Rossendorf, Research Site Leipzig, Leipzig, 04368, Germany. ${ }^{2}$ Department of Pharmaceutical and Medicinal Chemistry, University of Münster, Münster, 48149, Germany.

\section{Published: 11 March 2014}

\section{References}

1. Rühl T, Deuther-Conrad W, Fischer S, Günther R, Hennig L, Krautscheid L, Brust P: Cannabinoid Receptor Type 2 (CB2)-Selective N-Aryl-OxadiazolylPropionamides: Synthesis, Radiolabelling, Molecular Modelling and Biological Evaluation. Org Med Chem Lett 2012, 2:32

2. Günther R, Brust P: Synergistic approach of structure- based and ligandbased drug design for the development of selective cannabinoid receptor ligands. J Cheminform 2012, 4(Suppl 1):P11.

3. Gerebtzoff G, Seelig A: In Silico Prediction of Blood-Brain Barrier Permeation Using the Calculated Molecular Cross-Sectional Area as Main Parameter. J Chem Inf Model 2006, 6:2638-2650.

doi:10.1186/1758-2946-6-S1-O9

Cite this article as: Günther et al:: Development of cannabinoid receptor (CB 2 R) ligands for application in PET studies - where to attach the radiolabel? Journal of Cheminformatics 2014 6(Suppl 1):09.

\section{() Chemistry Central}

(c) 2014 Günther et al; licensee Chemistry Central Ltd. This is an Open Access article distributed under the terms of the Creative Commons Attribution License (http://creativecommons.org/licenses/by/2.0), which permits unrestricted use, distribution, and reproduction in any medium, provided the original work is properly cited. The Creative Commons Public Domain Dedication waiver (http://creativecommons.org/publicdomain/zero/1.0/) applies to the data made available in this article, unless otherwise stated. 